\title{
Cross-Regional Research in Demographic Impact on Safety Consciousness and Safety Citizenship Behavior of Construction Workers: A Comparative Study between Mainland China and Hong Kong
}

Xiangcheng MENG ( $\square$ xcmeng3-c@my.cityu.edu.hk)

City University of Hong Kong https://orcid.org/0000-0001-5715-683X

Alan H.S. CHAN

City University of Hong Kong

\section{Research article}

Keywords: comparative study, safety consciousness, demographic influence, cross-regional analysis, safety citizenship behavior

Posted Date: December 8th, 2020

DOI: https://doi.org/10.21203/rs.3.rs-122535/v1

License: @ (i) This work is licensed under a Creative Commons Attribution 4.0 International License. Read Full License 


\section{Abstract}

Background: The construction industry has rapidly developed with the continuous prosperity in Hong Kong and Mainland China, though accidents still occur with unacceptable frequency and severity. For promoting the safety issue of workers in construction industry, safety citizenship behavior (SCB) and safety consciousness (SC) were considered two influential constructs and further studied with integration of sociodemographic theories by scholars. However, no study has compared the SC and SCB of construction workers in terms of the demographic influence between Mainland China and Hong Kong.

Methods: To fill this research gap, this study investigated the territorial difference between these two regions by conducting a crosssectional questionnaire survey with recruitment of 253 Mainland construction workers and 256 Hong Kong construction workers.

Results: Significant similarities and differences of SC and SCB performance were revealed in terms of the workers with different genders, education levels, weekly working hours, and ages.

Conclusions: This study provides insights into the comparison of demographic influence on SC and SCB of construction workers between Hong Kong and Mainland China, which is unique as it can yield useful managerial knowledge relevant to the personal safety of targeted groups of construction workers with particular demographic characteristic in both regions and contribute the implementation of safety interventions in line with the specific distinction in territorial aspect.

\section{Highlights}

a. Regional similarities and differences on SC and SCB were revealed in HK and MC.

b. SC and SCB of HK workers were significantly higher than those of MC workers.

c. Education level positively affected SC and SCB in HK and MC.

d. Gender and workhour negatively impacted SC and SCB in MC and HK.

e. Age negatively impacted SC and SCB in HK, but caused positive effect in MC.

\section{Background}

Construction safety in China has become a primary concern for people due to the tremendous losses caused by work-related injuries of personnel (Shao et al., 2018; Li et al., 2018). The National Bureau of Statistic of China (2020) reported 5.21 injuries for every 100 workers and 14.31 fatalities for every 100,000 workers in Mainland China's construction industry in 2018. Similarly, high fatality rate of construction workers was observed in Hong Kong, which is the special administrative region of China. For example, 3.17 injuries were reported for every 100 workers and 12.51 fatalities were observed per 100,000 workers in 2018 (Labor Department of Hong Kong, 2018). These statistics highlight the urgent need for all personnel and academics concerned with occupational health and safety in both Mainland China and Hong Kong to reduce the number of the accidents.

To address this issue, scholars have considered safety citizenship behavior (SCB) and safety consciousness (SC) as noteworthy topics for investigation of personnel safety (Didla et al., 2009; Prussia et al. 2018; Oxley et al., 2018). Meng et al. (2019) and Meng and Chan (2020) further expanded the research of SC and SCB theories by developing the scale measurements and clarifying the corresponding demographic influence in Mainland China. However, the demographic influence on these constructs remain unknown in Hong Kong, let alone the comparison between Hong Kong and Mainland China. The research gap regarding the missing comparison of SC and SCB between two regions hindered the implementations of safety interventions related to SC and SCB that target specific groups of construction workers in these two regions. To fill such gap, this paper aims to identify and compare the difference in SC and SCB between Mainland China and Hong Kong, including the influence of demographic factors, such as gender, education level, age, and weekly working hours. This paper also provides a starting point for further research on the comparative study of demographic influences on the personnel safety of construction workers between regions. It then analyzes the reasons for and the resultant implications of the territorial differences, which can help these regions learn complementarily from one another.

\section{Theories of SC and SCB}

SC refers to the positive individual attitude and perception of environmental safety and working circumstances (Khan et al., 2018). The safety behavior of humans and their living environment can be enhanced by promoting safety consciousness (Prussia et al., 2018; Oxley et al., 2018). SCB is an organization-based voluntary behavior that focuses on improvement of mutual support and safety performance

Page 2/21 
at the organizational level (Hofmann and Morgeson, 1999). Compared with traditional safety behavior which focuses on the individual acts for ensuring personal safety, SCB is considered preferable for safety research because it is more related to the overall safety of the organization (Didla et al., 2009). Meng et al. (2019) developed scales to measure SC and SCB for the construction industry, which was also applied in the present study due to the considerable reliability and validity.

Comparing the safety constructs between these two regions is deemed feasible and valuable given the subtle relationship between Mainland China and Hong Kong. Specifically, Hong Kong functions within a legal environment with a capitalistic state but still partially adheres to traditional Chinese cultural patterns (Fong, 2017; Yeung, 2019). This study compares the SC and SCB between Mainland China and Hong Kong construction workers given that the safety of construction personnel is considered an important issue in both regions with different social and political conditions. For the former, personal unsafe behavior has been identified as the main cause of the high accident rates in its construction industry (Man et al., 2017; Wu et al., 2018). Accordingly, construction companies in Hong Kong have extensively implemented preventive measures, such as prevention-behavior-based safety management and supervisor-focused behavior-based safety method, to improve the safety of their workers (Li et al., 2015; Zhang et al., 2017). Meanwhile, the government of Mainland China has organized vocational education trainings to enhance the qualifications of construction workers in both theoretical and practical aspects (Nie et al., 2017).

\section{Demographic Influence}

For gender issue, females have been involved in fewer accidents and have a higher risk-avoiding consciousness than males (Galizzi and Tempesti, 2015). Nevertheless, some discussions persist about the regional ambiguity as the female workers sometimes suffer higher risk due to higher job stress and injury rate than male workers (Gordon, 2019). Education has been considered a direct and effective strategy for improving work capability and safety skills (Zhang and An, 2011), but some uncertainties regarding the regional influence of education level on the personal awareness and organizational safety of construction workers remain unaddressed due to the observed insignificant correlations (Pinion et al., 2018). For age, Schwatka and Rosecrance (2016) indicated that young workers will have a better safety at work compared with the older workers because of their better alertness to potential threats and higher physical capacities. However, some studies have reported the opposite conclusion regarding the regional age effect on safety of workers due to the finding of preferable personnel safety of elder workers with better safety experience (Magnavita, 2017; Idrees et al., 2017). Moreover, Lee and Lee (2017) pointed out the possibility of working-hour reduction to save the workers from unsafe situations. Skogstad et al. (2019) found that unreasonable working hours strongly increase the likelihood of increased occupational injuries and illnesses, which will also cause improper work shift that causes disorders in workers' lives and leads to health problems (Vanttola et al., 2019; Breloff et al., 2019). From the above, although the previous studies have proven that demographic factors significantly influence the safety of personnel, the effect will be influenced as the change of certain circumstances (such as location, culture and social background etc.), sometimes even convert the demographic influence from positive to negative (Kocourkova, 2016; Tsai et al., 2018). Therefore, to fill this research gap, the present study aims to conduct a cross-regional comparison between Hong Kong and Mainland China for the influence of demographic impact on SC and SCB, which are representative of the personnel safety of construction workers.

\section{Hypotheses}

Table 1 lists 17 hypotheses to clarify the cross-regional differences in the demographic effects on SC and SCB. The SC and SCB of Hong Kong workers were assumed to be higher than that of Mainland workers due to the higher level of education and technology acceptance during the rapid city development in recent years (Development Bureau of HKSAR, 2018). According to Meng and Chan (2020), the demographic influence on SC and SCB of Mainland workers was clarified by verifying the negative effect of gender and the positive effects of education level and age. Therefore, the trend of demographic influence in Hong Kong was hypothesized to be identical with Mainland China due to their similar cultural background of East Asia (Yeung, 2019). Moreover, the regional comparison of the intensity of the demographic effect was included in the hypotheses. 
Table 1

Hypotheses for demographic impact on SC and SCB of construction workers.

\begin{tabular}{|ll|}
\hline No. & Content \\
\hline H1 & Hong Kong construction workers perform higher SC and SCB than Mainland construction workers. \\
\hline H2.1 & Gender difference causes significant influence on the SC and SCB of construction workers in two regions. \\
\hline H2.2 & Gender causes stronger negative effect towards SC and SCB of Hong Kong workers. \\
\hline H2.3 & Gender causes stronger negative effect towards SC and SCB of workers from Mainland China. \\
\hline H3 & Education level causes significant influence on the SC and SCB of construction workers in two regions. \\
\hline H3.1 & Education level causes positive influence on the SC and SCB of construction workers in two regions. \\
\hline H3.2 & Education level causes stronger positive effect towards SC and SCB of Hong Kong workers. \\
\hline H3.3 & Education level causes stronger positive effect towards SC and SCB of workers from Mainland China. \\
\hline H4 & Age causes significant influence on the SC and SCB of Construction workers in two regions. \\
\hline H4.1 & Age causes positive influence on the SC and SCB of construction workers in two regions. \\
\hline H4.2 & Age causes stronger positive effect towards SC and SCB of Hong Kong workers. \\
\hline H4.3 & Age causes stronger positive effect towards SC and SCB of workers from Mainland China. \\
\hline H5 & Working hour causes significant influence on the SC and SCB of construction workers in two regions. \\
\hline H5.1 & Working hour causes negative influence on the SC and SCB of construction workers in two regions. \\
\hline H5.2 & Working hour causes stronger negative effect towards SC and SCB of Hong Kong workers. \\
\hline H5.3 & Working hour causes stronger negative effect towards SC and SCB of workers from Mainland China. \\
\hline
\end{tabular}

\section{Methodology}

\section{Questionnaire Survey}

A cross-sectional survey was conducted on site with the assistance of local worker unions and companies from September 1 st 2019 to April 30th 2020, by which the demographic information and SC and SCB data of the workers were collected. A total of 530 respondents were recruited from relevant construction enterprises (265 from Mainland China, and 265 from Hong Kong) to fill out the questionnaire, and 509 valid data were finally obtained (253 from Mainland China and 256 from Hong Kong). The questionnaire adopted in this study was previously developed and published by Meng et al. (2019) for measuring the correlation between SC and SCB, and is now widely applied in relevant studies due to its considerable reliability and validity (Li et al., 2020; Zhang et al., 2020; Meng and Chan, 2020). The present study further expanded the research to the cross regional comparison between Hong Kong and Mainland China about the demographic influence on SC and SCB of construction workers. The questionnaire was translated to Mandarin and Cantonese and some descriptions of the items were revised (names of applied construction regulations, safety terms, etc.) in line with the linguistic customs and local background of Mainland and Hong Kong workers, respectively. The questionnaire included 11 SC items and 12 SCB items, which were divided into four parts in line with the dimensions of SC and SCB. The SC dimensions involved conscientiousness, familiarity with safety regulations, dependency of work experience, and education on safety skills, while the SCB dimensions included self-control, relationship between superiors and subordinates, mutual aid, and participation in suggestion making. All items were rated on a five-point Likert scale ranging from 1 ("highly disagree") to 5 ("highly agree"). Before answering the questions, the respondents were asked for their demographic information, including their education level, age, gender, and weekly working hour. For research ethics, all respondents granted their informed consents by signing their names before answering the questionnaire. This study was approved by the Ethics Sub-committee of Research Committee in City University of Hong Kong.

\section{Data Analysis}

The collected data were assessed for their reliability and validity to test the effectiveness of the scales. The internal consistency reliability was evaluated to test the consistency of multiple items for measuring the same construct (Tavakol and Dennick, 2011).

Page $4 / 21$ 
Composite reliability was tested for each dimension to measure the reliability degree of compositional constructs (Ammerlaan et al., 2017). Convergent validity was assessed by using composite reliability together with factor loading and average variance extracted (AVE) (Cheung and Wong, 2017). Discriminant validity was evaluated by comparing the square root of AVE with its largest interconstruct correlations for a certain factor (Hair et al., 2010). Confirmatory factor analysis (CFA) was performed to evaluate the degree of fit of the measurement model to the research data. Goodness-of-fit indices (GFI), as well as root mean square residual (RMR), TuckerLewis index (TLI), root mean square error of approximation (RMSEA), chi-square divided by degree of freedom ( $\left.x^{2} / \mathrm{df}\right)$, and comparative fit index (CFI), were used to determine whether the CFA model has a good fit to the data (Hooper et al., 2008).

After the reliability and validity tests, descriptive analysis was conducted to present demographic distributions of the accumulated frequencies of reported SC and SCB scores for Hong Kong and Mainland China, and further compared for the significance of the between-group differences through the analysis of variance (ANOVA) in terms of different demographic information (Rouder et al., 2016). Moreover, multinomial regression was used to predict the possible outcomes of SC and SCB with different categorizations of demographic information (Ong and Puteh, 2017). Structural equation modeling (SEM) was applied to quantitatively measure the influence mechanism of demographic factors in two regions. All the demographic variables were coded according to their categories. Table 2 presents the detailed coding system for the demographic variables.

Table 2

Coding system for the demographic variables of questionnaire.

\begin{tabular}{|llll|}
\hline Age & Gender & Education level & Weekly working hours \\
\hline$[<20]-1$ & Male-0 & Junior middle school or below- & {$[<35]-1$} \\
\hline$[20-30]-2$ & Female- 1 & High school-2 & {$[35-40]-2$} \\
\hline $31-40]-3$ & & Technical school-3 & {$[41-45]-3$} \\
\hline$[41-50]-4$ & & Undergraduate or above-4 & {$[46-50]-4$} \\
\hline$>50]-5$ & & & {$[51-55]-5$} \\
& & & {$[>55]-6$} \\
\hline
\end{tabular}

\section{Results}

\section{Validity and Reliability Test}

The internal consistency reliability of the scale was tested by using Cronbach's alpha, and Table 3 presents the results. The Cronbach's alphas of SC and SCB for both Hong Kong and Mainland China exceeded 0.7, thereby indicating the high level of internal consistency reliability of the data (Tavakol and Dennick, 2011). Table 3 shows the good acceptances of the factor loadings (larger than 0.5) of all items for both regions. Table 4 shows that the composite reliabilities of SC and SCB for both regions exceeded 0.7, while the values of AVE were all larger than 0.5 (Hair et al., 2010). Good convergent validity was therefore verified as reflected in the acceptability of composite reliabilities, values of AVE, and factor loadings (Harrington, 2009; Cheung and Wang, 2017; Savalei, 2020). 
Table 3

Results of factor loadings and Cronbach's alphas.

\begin{tabular}{|c|c|c|c|c|c|c|}
\hline Safety construct & Dimension & Item & $\begin{array}{l}\text { Factor loading } \\
(\mathrm{HK})\end{array}$ & $\begin{array}{l}\text { Factor loading } \\
\text { (MC) }\end{array}$ & $\begin{array}{l}\text { Cronbach's } \\
\text { alpha (HK) }\end{array}$ & $\begin{array}{l}\text { Cronbach's } \\
\text { alpha } \\
\text { (MC) }\end{array}$ \\
\hline \multirow[t]{11}{*}{ Safety Consciousness } & \multirow[t]{3}{*}{ Education } & Item 1 & 0.756 & 0.702 & \multirow[t]{11}{*}{0.801} & \multirow[t]{11}{*}{0.800} \\
\hline & & Item 2 & 0.859 & 0.908 & & \\
\hline & & Item 3 & 0.854 & 0.825 & & \\
\hline & \multirow[t]{3}{*}{ Experience } & Item 4 & 0.819 & 0.831 & & \\
\hline & & Item 5 & 0.981 & 0.892 & & \\
\hline & & Item 6 & 0.895 & 0.910 & & \\
\hline & \multirow[t]{2}{*}{ Conscientiousness } & Item 7 & 0.937 & 0.880 & & \\
\hline & & Item 8 & 0.921 & 0.924 & & \\
\hline & \multirow[t]{3}{*}{ Regulation } & Item 9 & 0.873 & 0.884 & & \\
\hline & & $\begin{array}{l}\text { Item } \\
10\end{array}$ & 0.888 & 0.788 & & \\
\hline & & $\begin{array}{l}\text { Item } \\
11\end{array}$ & 0.922 & 0.808 & & \\
\hline \multirow{12}{*}{$\begin{array}{l}\text { Safety citizenship } \\
\text { behavior }\end{array}$} & \multirow[t]{3}{*}{ Mutual help } & Item 1 & 0.987 & 0.803 & \multirow[t]{12}{*}{0.883} & \multirow[t]{12}{*}{0.921} \\
\hline & & Item 2 & 0.973 & 0.851 & & \\
\hline & & Item 3 & 0.913 & 0.883 & & \\
\hline & \multirow[t]{3}{*}{ Relation exchange } & Item 4 & 0.807 & 0.929 & & \\
\hline & & Item 5 & 0.813 & 0.571 & & \\
\hline & & Item 6 & 0.892 & 0.843 & & \\
\hline & \multirow[t]{3}{*}{ Suggestion } & Item 7 & 0.957 & 0.862 & & \\
\hline & & Item 8 & 0.916 & 0.845 & & \\
\hline & & Item 9 & 0.894 & 0.866 & & \\
\hline & \multirow[t]{3}{*}{ Self-control } & $\begin{array}{l}\text { Item } \\
10\end{array}$ & 0.729 & 0.926 & & \\
\hline & & $\begin{array}{l}\text { Item } \\
11\end{array}$ & 0.906 & 0.933 & & \\
\hline & & $\begin{array}{l}\text { Item } \\
12\end{array}$ & 0.872 & 0.903 & & \\
\hline
\end{tabular}


Table 4

Results of composite reliability and average variance.

\begin{tabular}{|lllll|}
\hline Dimension & $\begin{array}{l}\text { Composite reliability } \\
(\mathrm{HK})\end{array}$ & $\begin{array}{l}\text { Average variance extracted } \\
(\mathrm{HK})\end{array}$ & $\begin{array}{l}\text { Composite reliability } \\
(\mathrm{MC})\end{array}$ & $\begin{array}{l}\text { Average variance extracted } \\
\text { (MC) }\end{array}$ \\
\hline Education & 0.863 & 0.679 & 0.855 & 0.666 \\
\hline Experience & 0.927 & 0.811 & 0.909 & 0.771 \\
\hline Conscientiousness & 0.926 & 0.863 & 0.897 & 0.814 \\
\hline Regulation & 0.923 & 0.800 & 0.866 & 0.685 \\
\hline Mutual help & 0.971 & 0.918 & 0.883 & 0.716 \\
\hline Relation exchange & 0.876 & 0.702 & 0.833 & 0.633 \\
\hline Suggestion & 0.944 & 0.851 & 0.893 & 0.735 \\
\hline Self-control & 0.876 & 0.704 & 0.943 & 0.847 \\
\hline
\end{tabular}

Tables 5 and 6 indicate that the largest Pearson correlation between different dimensions of SC and SCB is lower than the square root of AVE for each dimension. The discriminant validity of each dimension of SC and SCB was therefore verified (Falk and Biesanz, 2016).

Table 5

Inter-factor confirmatory correlations among the latent variables for Hong Kong.

\begin{tabular}{|c|c|c|c|c|c|c|c|c|}
\hline & Education & Experience & Conscientiousness & Regulation & $\begin{array}{l}\text { Mutual } \\
\text { help }\end{array}$ & $\begin{array}{l}\text { Relation } \\
\text { exchange }\end{array}$ & Suggestion & $\begin{array}{l}\text { Self- } \\
\text { control }\end{array}$ \\
\hline Education & 0.824 & & & & & & & \\
\hline Experience & $0.486^{\star \star}$ & 0.901 & & & & & & \\
\hline Conscientiousness & $0.596 * \star$ & $0.538 * \star$ & 0.929 & & & & & \\
\hline Regulation & $0.449 * \star$ & $0.318 * \star$ & 0.631 ** & 0.894 & & & & \\
\hline Mutual help & $0.643^{\star \star}$ & $0.689 * \star$ & 0.734 ** & $0.600 * \star$ & 0.958 & & & \\
\hline Relation exchange & $0.708^{\star \star}$ & $0.587^{\star \star}$ & $0.733^{\star \star}$ & 0.658 *ᄎ & $0.645^{\star \star}$ & 0.838 & & \\
\hline Suggestion & 0.717 ** & $0.535^{\star \star}$ & 0.742 ** & $0.673^{\star *}$ & $0.621^{\star \star}$ & $0.652^{\star \star}$ & 0.922 & \\
\hline Self-control & $0.674^{\star \star}$ & $0.678^{\star *}$ & 0.750 ** & $0.601 * \star$ & 0.646 ** & $0.647^{\star \star}$ & $0.616^{\star \star}$ & 0.839 \\
\hline
\end{tabular}

Table 6

Inter-factor confirmatory correlations among the latent variables for Mainland China.

\begin{tabular}{|c|c|c|c|c|c|c|c|c|}
\hline & Education & Experience & Conscientiousness & Regulation & $\begin{array}{l}\text { Mutual } \\
\text { help }\end{array}$ & $\begin{array}{l}\text { Relation } \\
\text { exchange }\end{array}$ & Suggestion & $\begin{array}{l}\text { Self- } \\
\text { control }\end{array}$ \\
\hline Education & 0.816 & & & & & & & \\
\hline Experience & $0.497 \star \star$ & 0.878 & & & & & & \\
\hline Conscientiousness & $0.586^{\star \star}$ & $0.545^{\star \star}$ & 0.902 & & & & & \\
\hline Regulation & $0.370 * \star$ & $0.266^{\star *}$ & 0.619 ** & 0.828 & & & & \\
\hline Mutual help & $0.699 * \star$ & 0.696 ** & $0.823^{\star \star}$ & $0.618^{\star \star}$ & 0.846 & & & \\
\hline Relation exchange & $0.693^{\star \star}$ & $0.639 * *$ & $0.768^{\star \star}$ & $0.669 \star \star$ & $0.723^{\star \star}$ & 0.796 & & \\
\hline Suggestion & $0.681^{\star \star}$ & $0.683^{\star \star}$ & $0.768^{\star \star}$ & $0.633^{\star \star}$ & $0.781^{\star \star}$ & $0.700 \star \star$ & 0.857 & \\
\hline Self-control & $0.705^{\star \star}$ & $0.707 * \star$ & $0.813^{* \star}$ & $0.633^{\star *}$ & $0.806 * \star$ & $0.790 * \star$ & $0.739 * \star$ & 0.920 \\
\hline
\end{tabular}

As depicted in Table 7, the CFA model of Hong Kong was tested using the following criteria: $\left(\chi^{2} / d f\right)=3.292, \mathrm{TLI}=0.954, \mathrm{CFI}=0.969$, $\mathrm{RMSEA}=0.021, \mathrm{GFI}=0.921$, and RMR $=0.049$, which altogether demonstrated a remarkable degree of fit of the measurement model to 
the questionnaire data. For Mainland China, a high degree of fit was also verified between the data and the model $\left(\chi^{2} / d f=2.364, T L I=\right.$ 0.967, $\mathrm{CFI}=0.977, \mathrm{RMSEA}=0.044, \mathrm{GFI}=0.898$, and RMR $=0.027$ (Hooper et al., 2008).

Table 7

Criteria of CFA results for Hong Kong and Mainland China.

\begin{tabular}{|lllllll|}
\hline Questionnaire & $\boldsymbol{\chi}^{2} / \boldsymbol{d f}$ & RMR & GFI & TLI & CFI & RMSEA \\
\hline Hong Kong & 3.292 & 0.049 & 0.921 & 0.954 & 0.969 & 0.021 \\
\hline Mainland & 2.364 & 0.027 & 0.898 & 0.967 & 0.977 & 0.044 \\
\hline Criterion & $<5$ & $<0.05$ & $>0.9$ & $>0.9$ & $>0.9$ & $<0.05$ \\
\hline
\end{tabular}

\section{Descriptive Analysis}

Table 8 shows the demographic distributions of the accumulated frequencies of reported SC and SCB scores for both Mainland China and Hong Kong. The highest proportion of respondents was observed to be 31-40 years old for two regions (63 from Mainland China, and 64 from Hong Kong). Most of the respondents had high school diploma (71 from Mainland China, and 98 from Hong Kong) and worked 41 to 45 hours per week (52 from Mainland China, and 58 from Hong Kong). Overall, male construction workers had higher SC and SCB scores than their female counterparts. Hong Kong construction workers showed higher SC and SCB scores than their Mainland counterparts.

Table 8

Statistical Analysis of the SC and SCB performances of construction workers.

\begin{tabular}{|c|c|c|c|c|c|c|c|c|c|c|c|}
\hline \multicolumn{2}{|c|}{ Demographic } & \multicolumn{5}{|c|}{ Mainland China (253) } & \multicolumn{5}{|c|}{ Hong Kong (256) } \\
\hline & & $\mathbf{N}$ & $\begin{array}{l}\text { Average } \\
\text { SC }\end{array}$ & $\begin{array}{l}\text { Average } \\
\text { SCB }\end{array}$ & $\begin{array}{l}\text { SD } \\
\text { (SC) }\end{array}$ & $\begin{array}{l}\text { SD } \\
\text { (SCB) }\end{array}$ & $\mathbf{N}$ & $\begin{array}{l}\text { Average } \\
\text { SC }\end{array}$ & $\begin{array}{l}\text { Average } \\
\text { SCB }\end{array}$ & $\begin{array}{l}\mathrm{SD} \\
\text { (SC) }\end{array}$ & $\begin{array}{l}\text { SD } \\
\text { (SCB) }\end{array}$ \\
\hline \multirow[t]{2}{*}{ Gender } & Male & 141 & 3.981 & 4.001 & 0.355 & 0.411 & 142 & 4.263 & 4.187 & .247 & .326 \\
\hline & Female & 112 & 3.472 & 3.362 & 0.533 & 0.583 & 114 & 3.613 & 3.523 & .344 & .387 \\
\hline \multirow[t]{4}{*}{$\begin{array}{l}\text { Education } \\
\text { level }\end{array}$} & $\begin{array}{l}\text { Junior middle } \\
\text { school or below }\end{array}$ & 58 & 2.951 & 3.042 & 0.317 & 0.433 & 42 & 3.175 & 3.265 & 0.324 & 0.437 \\
\hline & High school & 71 & 3.657 & 3.604 & 0.287 & 0.324 & 98 & 3.619 & 3.515 & 0.279 & 0.343 \\
\hline & Technical school & 69 & 4.099 & 3.951 & 0.197 & 0.216 & 63 & 4.242 & 4.253 & 0.165 & 0.221 \\
\hline & $\begin{array}{l}\text { Undergraduate or } \\
\text { above }\end{array}$ & 55 & 4.299 & 4.291 & 0.277 & 0.244 & 53 & 4.740 & 4.431 & 0.166 & 0.163 \\
\hline \multirow[t]{5}{*}{ Age } & $<20$ & 41 & 3.301 & 3.383 & 0.175 & 0.127 & 47 & 4.451 & 4.441 & 0.186 & 0.177 \\
\hline & $20-30$ & 55 & 3.421 & 3.499 & 0.144 & 0.186 & 53 & 4.296 & 4.315 & 0.193 & 0.216 \\
\hline & $31-40$ & 63 & 3.681 & 3.658 & 0.177 & 0.218 & 64 & 3.858 & 3.721 & 0.279 & 0.278 \\
\hline & $41-50$ & 50 & 4.156 & 3.951 & 0.262 & 0.215 & 57 & 3.578 & 3.411 & 0.398 & 0.349 \\
\hline & $>50$ & 44 & 4.257 & 4.123 & 0.390 & 0.325 & 35 & 3.361 & 3.272 & 0.410 & 0.395 \\
\hline \multirow{6}{*}{$\begin{array}{l}\text { Weekly } \\
\text { working } \\
\text { hours }\end{array}$} & $<35$ & 37 & 4.391 & 4.358 & 0.180 & 0.249 & 28 & 4.428 & 4.461 & 0.197 & 0.174 \\
\hline & $36-40$ & 41 & 4.051 & 4.142 & 0.186 & 0.233 & 42 & 4.233 & 4.204 & 0.154 & 0.251 \\
\hline & $41-45$ & 52 & 3.734 & 3.761 & 0.212 & 0.282 & 58 & 4.159 & 4.062 & 0.257 & 0.238 \\
\hline & $46-50$ & 49 & 3.615 & 3.593 & 0.240 & 0.332 & 55 & 3.834 & 3.782 & 0.368 & 0.385 \\
\hline & $51-55$ & 37 & 3.442 & 3.378 & 0.333 & 0.413 & 40 & 3.532 & 3.404 & 0.433 & 0.388 \\
\hline & $>55$ & 37 & 3.328 & 3.055 & 0.325 & 0.419 & 33 & 3.341 & 3.123 & 0.435 & 0.432 \\
\hline \multicolumn{2}{|l|}{$\begin{array}{l}\text { Total } \\
\text { average }\end{array}$} & & 3.756 & 3.718 & 0.669 & 0.802 & & 3.974 & 3.891 & 0.674 & 0.821 \\
\hline
\end{tabular}


The average scores of every item for SC and SCB were presented on a radar plot (Fig. 1). Each questionnaire item was set as the axis, and the average score of each item was represented. As shown in Fig. 1, the Hong Kong respondents only had two items lower than those of Mainland counterparts (SC8: "You think you should strengthen personal safety consciously during the construction process," and SC9: "You are well aware of the terms of the building industry standards").

\section{ANOVA}

For the comparison of the demographic differences in SC and SCB between Hong Kong and Mainland China, Tables 9 and 10 depict the results of ANOVA to evaluate the significances of distinctions. Table 9 reveals significant differences in the SC and SCB of construction workers between regions $(P<0.05)$. As shown in Sect. 4.1, the SC and SCB of Hong Kong workers (3.974 and 3.891, respectively) were significantly higher than those of Mainland workers (3.756 and 3.718, respectively).

Table 9

ANOVA results for SC and SCB in Hong Kong and Mainland China.

\begin{tabular}{|c|c|c|c|c|c|c|c|}
\hline & & & Quadratic sum & Df & Mean square & $F$ & $P$ (Sig.) \\
\hline \multirow[t]{6}{*}{ Region } & \multirow[t]{3}{*}{ SC } & Interclass & 1.311 & 1 & 1.311 & 5.685 & 0.01 ** \\
\hline & & Intraclass & 116.899 & 507 & 0.231 & & \\
\hline & & Total & 118.210 & 508 & & & \\
\hline & \multirow[t]{3}{*}{ SCB } & Interclass & 1.655 & 1 & 1.654 & 5.267 & $0.01^{\star *}$ \\
\hline & & Intraclass & 159.304 & 507 & 0.314 & & \\
\hline & & Total & 160.959 & 508 & & & \\
\hline
\end{tabular}

Table 10

Comparative ANOVA results for the SC and SCB of construction workers.

\begin{tabular}{|c|c|c|c|}
\hline Feature & Constructs & Sig of HK $(P)$ & Sig of $\mathrm{MC}(P)$ \\
\hline \multirow[t]{2}{*}{ Gender } & SC & $0.000^{\star \star \star \star}$ & $0.000^{\star \star \star \star}$ \\
\hline & SCB & $0.000^{\star \star \star \star}$ & $0.000^{\star \star \star \star}$ \\
\hline \multirow[t]{2}{*}{ Age } & SC & $0.000^{\star \star \star \star}$ & $0.000^{\star \star \star \star}$ \\
\hline & SCB & $0.000^{\star \star \star \star}$ & $0.000^{\star \star \star \star}$ \\
\hline \multirow[t]{2}{*}{ Education level } & $\mathrm{SC}$ & $0.000^{\star \star \star \star}$ & $0.000^{\star \star \star \star}$ \\
\hline & SCB & $0.000^{\star \star \star \star}$ & $0.000^{\star \star \star \star}$ \\
\hline \multirow[t]{2}{*}{ Weekly working hours } & SC & $0.000^{\star \star \star \star}$ & $0.000^{\star \star \star \star}$ \\
\hline & SCB & $0.000^{\star \star \star \star}$ & $0.000^{\star \star \star \star}$ \\
\hline
\end{tabular}

Table 10 reveals that all demographic variables significantly differentiate the SC and SCB of construction workers in Hong Kong and Mainland China, given that the values of $P$ were all less than 0.001 . Combined with the statistical analysis presented in Sect. 4.1, the SC and SCB of male workers were significantly higher than those of female workers in two regions. SC and SCB of workers with higher education level were significantly higher than those with lower education level in both regions. Workers with longer working hours reported significantly lower SC and SCB in two regions. Older construction workers had significantly higher SC and SCB than younger workers in Mainland China, whereas the SC and SCB decreased along with increasing age in Hong Kong. 
Tables 11 and 12 present the multinomial regression results for SC and SCB of construction workers in Mainland China and Hong Kong, respectively. All coefficients of the demographic variables were verified as significant in these two regions, given that the values of $P$ were all less than 0.001 . No multiple collinearity was observed among the different factors in accordance with the acceptable tolerance and variance inflation factor (VIF). The regression constants refer to the intercept of the function. For Hong Kong, the regression constants for SC and SCB were 3.525 and 4.588, respectively, indicating greater intercepts compared with those of Mainland China (2.226 for SC and 3.360 for $S C B$ ). The values of adjusted $R^{2}$ represent the degrees of explanation of the variables toward the variations of SC and SCB.

Table 11

Multinomial regression of the SC and SCB of construction workers in Hong Kong.

\begin{tabular}{|c|c|c|c|c|c|c|c|c|c|}
\hline \multicolumn{2}{|c|}{ Regression models } & \multicolumn{2}{|c|}{$\begin{array}{l}\text { Unstandardized } \\
\text { coefficients }\end{array}$} & \multirow{2}{*}{$\begin{array}{l}\text { Standardized } \\
\text { coefficients } \\
\text { Beta }\end{array}$} & \multirow[t]{2}{*}{$\mathrm{t}$} & \multirow[t]{2}{*}{$P($ Sig. $)$} & \multicolumn{2}{|l|}{$\begin{array}{l}\text { Collinearity } \\
\text { statistics }\end{array}$} & \multirow[t]{2}{*}{$\begin{array}{l}\text { Adjusted } \\
\mathrm{R}^{2}\end{array}$} \\
\hline & & B & Std. Error & & & & Tolerance & VIF & \\
\hline \multirow[t]{5}{*}{ SC } & (Constant) & 3.525 & 0.154 & & 29.341 & 0.000 & & & \multirow[t]{5}{*}{0.684} \\
\hline & Gender & -0.336 & 0.066 & -0.244 & -4.127 & 0.000 & 0.698 & 1.433 & \\
\hline & Age & -0.324 & 0.038 & -0.415 & -6.740 & 0.000 & 0.642 & 1.557 & \\
\hline & $\begin{array}{l}\text { Education } \\
\text { level }\end{array}$ & 0.163 & 0.028 & 0.328 & 5.839 & 0.000 & 0.774 & 1.293 & \\
\hline & $\begin{array}{l}\text { Working } \\
\text { hours }\end{array}$ & -0.149 & 0.027 & -0.268 & 5.570 & 0.000 & 0.879 & 1.138 & \\
\hline \multirow[t]{5}{*}{ SCB } & (Constant) & 4.588 & 0.159 & & 28.785 & 0.000 & & & \multirow[t]{5}{*}{0.749} \\
\hline & Gender & -0.321 & 0.068 & -0.257 & -4.726 & 0.000 & 0.643 & 1.556 & \\
\hline & Age & -0.294 & 0.039 & -0.429 & -7.574 & 0.000 & 0.752 & 1.330 & \\
\hline & $\begin{array}{l}\text { Education } \\
\text { level }\end{array}$ & 0.194 & 0.029 & 0.347 & 6.736 & 0.000 & 0.761 & 1.314 & \\
\hline & $\begin{array}{l}\text { Working } \\
\text { hours }\end{array}$ & -0.174 & 0.027 & -0.279 & -6.499 & 0.000 & 0.899 & 1.112 & \\
\hline
\end{tabular}

Note: VIF: Variance Inflation Factor, which should be less than 10 to indicate the absence of collinearity. 
Table 12

Multinomial regression of the SC and SCB of construction workers in Mainland China.

\begin{tabular}{|c|c|c|c|c|c|c|c|c|c|}
\hline \multicolumn{2}{|c|}{ Regression models } & \multicolumn{2}{|c|}{$\begin{array}{l}\text { Unstandardized } \\
\text { coefficients }\end{array}$} & \multirow{2}{*}{$\begin{array}{l}\text { Standardized } \\
\text { coefficients } \\
\text { Beta }\end{array}$} & \multirow[t]{2}{*}{$\mathrm{T}$} & \multirow[t]{2}{*}{$P($ Sig. $)$} & \multicolumn{2}{|l|}{$\begin{array}{l}\text { Collinearity } \\
\text { statistics }\end{array}$} & \multirow[t]{2}{*}{$\begin{array}{l}\text { Adjusted } \\
\mathrm{R}^{2}\end{array}$} \\
\hline & & B & Std. Error & & & & Tolerance & VIF & \\
\hline \multirow[t]{5}{*}{ SC } & (Constant) & 2.226 & 0.060 & & 37.327 & 0.000 & & & \multirow[t]{5}{*}{0.941} \\
\hline & Age & 0.271 & 0.033 & 0.492 & 8.126 & 0.000 & 0.926 & 1.080 & \\
\hline & Education & 0.108 & 0.039 & 0.161 & 2.778 & 0.006 & 0.278 & 3.592 & \\
\hline & Gender & -0.052 & 0.026 & -0.037 & -2.000 & 0.047 & 0.868 & 1.152 & \\
\hline & $\begin{array}{l}\text { Working } \\
\text { hours }\end{array}$ & -0.145 & 0.037 & -0.328 & -3.944 & 0.000 & 0.289 & 3.456 & \\
\hline \multirow[t]{5}{*}{ SCB } & (Constant) & 3.360 & 0.371 & & 9.063 & 0.000 & & & \multirow[t]{5}{*}{0.948} \\
\hline & Age & 0.286 & 0.045 & 0.450 & 6.435 & 0.000 & 0.912 & 1.096 & \\
\hline & Education & 0.119 & 0.052 & 0.153 & 2.295 & 0.023 & 0.322 & 3.106 & \\
\hline & Gender & -0.122 & 0.035 & -0.076 & -3.520 & 0.001 & 0.794 & 1.259 & \\
\hline & $\begin{array}{l}\text { Working } \\
\text { hours }\end{array}$ & -0.181 & 0.049 & -0.354 & -3.690 & 0.000 & 0.381 & 2.625 & \\
\hline
\end{tabular}

\section{Demographic Influence Modeling}

To compare the influence mechanism of demographic variables on the SC and SCB of construction workers in Hong Kong and Mainland China quantitatively, structural equation modeling (SEM) was performed to estimate the impact of different demographic variables on SC and SCB, as shown in Figs. 2 and 3. Table 13 depicts that both SC and SCB models exhibited good fit to the data. As is vividly shown in the figures, the negative effects in the Mainland China model were verified in line with the coefficients of gender (coded as 0 for male and 1 for female) and weekly working hours (WH). Meanwhile, age and education level (EL) showed positive effects on SC and SCB. For Hong Kong, only EL showed a positive effect on SC and SCB, whereas gender, age, and WH showed negative effects to both safety constructs according to their coefficients.

Table 13

Model fit indices for the demographic influence of the SEMs.

\begin{tabular}{|lcccccccc|}
\hline & $\chi^{2} / d f$ & SRMR & TLI & CFI & RMSEA & GFI & AGFI & PGFI \\
\hline Hong Kong model & 2.139 & 0.026 & 0.978 & 0.988 & 0.057 & 0.912 & 0.837 & 0.591 \\
\hline Mainland China model & 2.966 & 0.042 & 0.965 & 0.977 & 0.065 & 0.903 & 0.924 & 0.598 \\
Standard & $\leq 5$ & $\leq 0.08$ & $\geq 0.9$ & $\geq 0.9$ & $\leq 0.08$ & $\geq 0.5$ & $\geq 0.8$ & $\geq 0.5$ \\
\hline
\end{tabular}

In order to compare the demographic influence on SC and SCB between Hong Kong and Mainland China, test of invariance routine was conducted to identify performing distinction of the research model between regions (Hagger et al., 2007). The differences of Goodnessof-fit indices were examined and listed in Table 14, which reveals significant distinction of SEM between two regions in terms of demographic influence on SC and SCB (Hagger et al., 2007). 
Comparisons for cross-regional Structural Equation Models.

\begin{tabular}{|c|c|c|c|c|}
\hline Comparison & $\Delta S B-\chi^{2}$ & $\Delta \mathrm{df}$ & $\triangle N N F I$ & $\Delta \mathrm{CFI}$ \\
\hline Hong Kong vs Mainland China & $66.16^{\star \star}$ & $19 * *$ & $0.010 \star \star$ & $0.011^{\star \star}$ \\
\hline
\end{tabular}

Furthermore, the significances of different influence paths were verified as shown in Table 15, in which all paths were significant given that the $P$ values were all less than 0.05 , though the strength of the demographic effect was partially different between two regions. Specifically, a stronger effect of gender was shown in Mainland China, while the stronger influences of workhour and age were found in Hong Kong.

Table 15

Significance of influence paths among the demographic variables and safety constructs.

\begin{tabular}{|c|c|c|c|c|c|c|}
\hline Path & & & Path coefficient (HK) & Sig $(H K)$ & Path coefficient (MC) & Sig (MC) \\
\hline SC & $<-$ & EL & 0.672 & $\star \star \star$ & 0.712 & $\star \star \star *$ \\
\hline SC & $<-$ & Gender & -0.133 & * & -0.631 & $\star \star \star$ \\
\hline SC & $<-$ & WH & -0.888 & 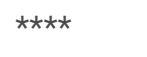 & -0.554 & $\star \star \star$ \\
\hline SC & $<-$ & Age & -0.781 & 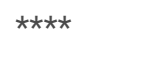 & 0.662 & $\star \star \star *$ \\
\hline SCB & $<-$ & Age & -0.794 & $\star * \star *$ & 0.674 & $\star \star \star$ \\
\hline SCB & $<-$ & EL & 0.654 & $\star \star \star$ & 0.693 & $\star \star \star$ \\
\hline SCB & $<-$ & Gender & -0.179 & ** & -0.681 & $\star \star \star ~$ \\
\hline $\mathrm{SCB}$ & $<-$ & WH & -0.813 & 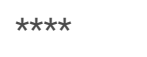 & -0.514 & $\star \star \star$ \\
\hline
\end{tabular}

Therefore, $\mathrm{H} 1$ was verified because the SC and SCB of Mainland workers were lower than those of Hong Kong workers. $\mathrm{H} 2, \mathrm{H} 2.1$ and $\mathrm{H} 2.3$ were all accepted since the significant negative influence of gender was greater in Mainland China (0.005 significance level) compared with that in Hong Kong ( 0.05 significance level), which further leaded to the rejection of H2.2. H3 and H3.1 were supported but $\mathrm{H} 3.2$ and $\mathrm{H} 3.3$ were rejected given the positive effect of education on SC and SCB in two regions which were all significant at 0.005 level. $\mathrm{H} 4$ was accepted due to the significance of age effect but $\mathrm{H} 4.1, \mathrm{H} 4.2$ and $\mathrm{H} 4.3$ were all rejected given the negative effect of age in Hong Kong and positive effect in Mainland China. H5, H5.1 and H5.2 were supported given the stronger negative effects of weekly working hour in Hong Kong at 0.001 significance level, which further leaded to the rejection of H5.3.

\section{Discussions}

\section{Regional Similarity}

\section{Territorial Education Strategies}

Workers with insufficient education have a limited understanding of safety and working capabilities (Vaismoradi et al., 2016). Male and female workers in both regions with higher education were reported to have higher SC and SCB scores. And the influence of education on SC and SCB were significant at 0.005 level in both Hong Kong and Mainland China. The findings are in line with the previous research examining the demographic influence of SC and SCB (Meng and Chan, 2020), which validated the effectiveness of education in enhancing the SC and SCB of workers. Generally, the education level of Mainland workers is lower than Hong Kong workers because more of the latter obtained high school degree (98 respondents), and more of the former only obtained junior middle school degree or below (58 respondents). The relevant Mainland authorities should be concerned that the lower education level of the workers will create a huge obstacle toward the understanding of the safety education because of the shortages of general knowledge and learning capacities (Podorova et al., 2019). Therefore, using graphical presentation and example illustration is recommended in areas that are difficult to understand while conducting on-job campaigns and safety courses, preferably with rewards and incentives for workers to ensure the learning initiative, such as safety performance reward or paid learning time (Cheng et al., 2020). However, in this study, Hong 
Kong respondents reported lower scores in terms of the safety regulation of construction industry (Item: SC9) than their Mainland counterparts. Therefore, worker's education in Hong Kong should be more emphasized on the learning of the construction regulation to facilitate their proper understanding and familiarity to the common ordinance and laws of Hong Kong construction industry, such as "Fire Safety (Building) Ordinance, CAP 572" and "Building Ordinance, CAP 123".

\section{Workhour Design}

Workhour was identified in both regions as a significant predictor of occupational injuries, with more workload corresponding to lower SC and SCB. One possible explanation for such finding is that a prolonged working time will exhaust workers and reduce their concentration and consciousness, thereby negatively affecting their attitudes and organizational participations toward work safety (Lee and Lee, 2016; Park et al., 2019). To solve this problem, working duration should be properly scheduled to optimize the working efficiency and safety performance of construction workers (Meng et al., 2019). Rest interval should be integrated to guarantee the recovery of worker's physical strength. Additionally, adverse weather conditions should be considered in the design of workhour as a stressor of workload (Calkins et al., 2019). To illustrate, the outdoor works such as masonry and earth excavation starting from $12 \mathrm{pm}$ during midsummer should be suspended and delayed until $3 \mathrm{pm}$ due to the physical consumption and work burnout caused by high temperature.

\section{Regional Differentia}

\section{SC and SCB}

$\mathrm{SC}$ of the respondents from Hong Kong is higher than that of the respondents from Mainland China, which may be attributed to the carrying out of safety incentive system and high level of professional education in Hong Kong construction industry. The Hong Kong government has introduced a "Pay for Safety Scheme" project, where contractors planning to tender for public infrastructural works can include several safety-related tasks as part of their bills of quantities. These contractors will be paid for these items when these tasks are successfully implemented and achieved, which can increase the conscientiousness and motivation of managers and workers (Yiu et al., 2018). Moreover, the Hong Kong Occupational Safety and Health Council has organized training courses since 1988 for construction personnel who aimed to promote site safety (HKOHSC, 2020). Therefore, the construction management of Mainland China is suggested to take Hong Kong as an example by conducting safety incentive system and site safety education for workers to enhance both conscientiousness and safety knowledge, thereby further improving SC (Meng et al., 2019).

Construction workers in Hong Kong were verified to have better SCB than their counterparts in Mainland China because of the high education level (more Hong Kong respondents obtained a high school degree). The management and supervisory staff groups in the Hong Kong are highly educated and concerned about the safety of their coworkers and employees (Ho, 2016). The managements believe that the poor safety of personnel will negatively affect the reputations of the company and induce high compensations. Therefore, they tend to play a proactive role to guarantee the safety of their workers and protect the interests of their organizations (Rowlinson, 2003; Ying et al., 2017). By contrast, the managers of construction companies in Mainland China lack authority to make decisions and are not responsible for the profits and losses of the projects. Therefore, they generally lack the motivation to carry out their work with cost-effectiveness (Yang et al., 2017; Tan et al., 2017). The present study recommends that the relevant authorities and management of Mainland China conduct a reward mechanism for safety cooperation of construction employees such as remuneration and extra vacation for personnel who makes prominent contribution to organizational safety (Ji et al., 2018), as well as the continuing education of high-quality leadership for construction management and group leaders (Mohammad et al., 2016) to improve the SCB of construction workers by learning from the experience of Hong Kong.

\section{Aging Problem}

The elder workers in Mainland China reported higher SC and SCB, which perceive more support and encouragement from organization and are more willing to wear the safety equipment than their younger counterparts (Stoilkovska et al., 2015). These elder workers also realize that only few job opportunities are available to them, thereby driving them to show higher commitment to their work and more willingness to obey safety regulations of the supervisor (Yu, 2016; Chih et al., 2016). By contrast, the negative relationship of age with SC and SCB in the construction industry of Hong Kong was clarified, which is mostly attributed to the declining trajectories of the working ability and retirement pathways of the Hong Kong workers ( $\mathrm{Ng}$ and Chan, 2015). Specifically, Peng and Chan (2019) considered the reduced working capacity and psychological engagement as the obstacles to personnel safety among the elder workers in Hong Kong. They further attributed the reduced risk perception and avoidance of Hong Kong elder workers to the changes in the trajectories of working ability along with age (Peng and Chan, 2020), which negatively affect the conscientiousness of risk avoidance and working 
cooperation (Skibiński et al., 2016; Allan, 2017). In addition, the findings reveal that additional workhours will cause stronger negative effect on SC and SCB of Hong Kong workers than that of Mainland workers, which is mainly due to the large proportion of aging workforce of Hong Kong construction industry with insufficient physical and psychological strength to achieve consciousness concentrating and provide altruistic assistance under the excessive workload (Peng and Chan, 2019; Li et al., 2019).

Therefore, the relevant authorities and managements of the Hong Kong construction companies are advised to improve the physical capacity of elder workers by organizing trans-theoretical model-based educational programs involving different activities, such as lectures, training workshops, group discussions, and propagandas regarding regular physical activity (Poscia et al., 2016). Moreover, concerned authorities could hold safety promotional campaigns to increase the mental health of elder workers, preferably involving control interventions, job stress prevention, help-seeking promotion, mental health literacy improvement, and the establishment of positive leadership practices (LaMontagne et al., 2014).

\section{Female Caring}

The SC and SCB of female workers are generally lower than their male counterparts. The female workers in Mainland China performed worse SC and SCB under a stronger gender effect than their Hong Kong counterparts. The findings are in line with the research of Meng and Chan (2020), which mainly attributed the poor SC and SCB of Mainland female workers to their working marginalization due to the hegemonic masculinity of males, which is specifically generated from the traditional culture in Mainland China and not predominant in Hong Kong due to the difference of regional culture and social background (Jones, 2016). Therefore, the intensity of gender effect in Hong Kong is relatively moderate. The work schedule and condition should be specially designed for female workers with the consideration of ensuring their occupational health, especially for Mainland China (Villanueva et al., 2017; Meng and Chan, 2020). The heavy jobs such as manual handling and reinforcing works should be reduced for female workers due to their low physical capacity, and additional rest interval should be properly scheduled (Li et al., 2019). Also, the perception of organizational affiliation should be promoted for female workers by increasing the support and commitment from all levels of supervision and management through practical measure, such as the Given Voice to Value approach, so as to help them achieve high cohesion and unity with group members (Curtis et al., 2018).

\section{Conclusions}

\section{Theoretical and Practical Contributions}

This study provides insights into the comparison of demographic influence on SC and SCB of construction workers between Hong Kong and Mainland China. As one of its important theoretical contributions, this study firstly recommends a specific focus on the territorial comparison of SC and SCB to design targeted and effective measures and suggestions for SC and SCB improvement. Specifically, the gender and workhour caused negative effect towards SC and SCB in both regions, while the effect of education was positive. SC and SCB of Hong Kong workers were higher than those of Mainland workers. Although the influence of age was shown negative in Hong Kong, the positive impact of age was verified in Mainland China.

The insights generated by this study offer the construction management with practical implications. The findings put forward a territorial plan of safety education for construction workers in Hong Kong and Mainland China, respectively. Moreover, the optimized workload and work condition are discussed with consideration of environmental and gender characteristics in both regions. In addition, the construction management is recommended to carry out safety incentive and reward mechanisms in Mainland China for cooperation and contribution of construction employees, while the Hong Kong construction companies should improve the work safety of elder workers by organizing trans-theoretical model-based educational programs.

\section{Limitations}

This research still has certain limitations. First, the scope of demographic information can be further expanded and the length of working service can be added as the additional demographic information to enhance the effectiveness of the research. Second, the data obtained from the survey were cross-sectional, and the tested effects of demographic variables only focused in a static time point instead of the overall process, which may partially eliminate the interpretation of the influence mechanism toward SC and SCB. Future research is suggested to improve the data collection process by distributing and collecting data over multiple periods of time.

\section{Abbreviations}


SC: Safety consciousness; SCB: Safety citizenship behaviour; HK: Hong Kong; MC: Mainland China; AVE: Average variance extracted; CFA: Confirmatory factor analysis; GFI: Goodness-of-fit indices; RMR: Root mean square residual; TLI: Tucker-Lewis index; RMSEA: Root mean square error of approximation; WH: Weekly working hours; EL: Education level. VIF: Inflation factor; SEM: Structural equation modeling; CFI: Comparative fit index.

\section{Declarations}

Ethics approval and consent to participate: This research gained approval by the Ethics Sub-committee of Research Committee in City University of Hong Kong for research with human safety. All participants signed the informed consent with their signature before data collection commenced.

Consent for publication: Not applicable.

Availability of data and material: The datasets used and analysed during the current study are available from the corresponding author on reasonable request. Interested people may contact the corresponding author by email xcmeng3-c@my.cityu.edu.hk to request the research data.

Competing interests: The authors declare no conflict of interest.

Funding: The work described in this paper did not receive any funding.

Authors' contributions: XM: Conceptualization; Data curation; Formal analysis; Investigation; Methodology; Resources; Software; Writing - original draft. AHSC: Conceptualization; Data curation; Formal analysis; Project administration; Supervision; Validation; Writing review \& editing. All authors read and approved the manuscript.

Acknowledgements: The authors wish to express profound gratitude to Mr. Fang Yong Le from the VANK Real Estate Company, Mr. Luk Chong Wai from Hong Kong Urban Renewal Authority, Mr. Chan Tze Cheuk from WSP Asia (Holdings) Limited, Ms. PENG Lu and Ms. WONG Ka Po from Hong Kong Construction Industry Employees General Union, for their considerable assistances during the process of questionnaire distribution and data collection.

\section{References}

1. Allan JA. Intentional Personality Change: The Development and Evaluation of a Group Based Program to Increase Conscientiousness. Doctor of Philosophy dissertation. 2017; University of Wollongong. https://ro.uow.edu.au/theses1/370.

2. Ammerlaan JW, van Os-Medendorp H, Sont JK, Elsworth GR, Osborne RH. Validation of the dutch version of the health education impact questionnaire (HEIQ) and comparison of the Dutch translation with the English, German and French HEIQ. Health Qual Life Outcomes 2017; 15 doi:10.1186/s12955-017-0601-4.

3. Breloff SP, Dutta A, Dai F, Sinsel EW, Warren CM, Ning X, Wu JZ. Assessing work-related risk factors for musculoskeletal knee disorders in construction roofing tasks. Appl Ergon. 2019;81:102901. doi:10.1016/j.apergo.2019.102901.

4. Calkins MM, Bonauto D, Hajat A, Lieblich M, Seixas N, Sheppard L, Spector JT. A case-crossover study of heat exposure and injury risk among outdoor construction workers in Washington State. Scand J Work Environ Health. 2019;45:588-99. doi:10.5271/sjweh.3814.

5. Cheng R, Orosz G, Murray RM, Burdick JW. End-to-end safe reinforcement learning through barrier functions for safety-critical continuous control tasks. In Proceedings of the AAAI Conference on Artificial Intelligence 2020; 33: 3387-3395. doi: https://doi.org/10.1609/aaai.v33i01.33013387.

6. Cheung GW, Wang C. Current approaches for assessing convergent and discriminant validity with SEM: Issues and solutions. In Academy of Management Proceedings, 2017; pp. 12706. Briarcliff Manor, NY 10510: Academy of Management. doi:10.5465/AMBPP.2017.12706abstract.

7. Chih YY, Kiazad K, Zhou L, Capezio A, Li MD, Restubog SL. Investigating Employee Turnover in the Construction Industry: A Psychological Contract Perspective. J Constr Eng Manag. 2016;142:04016006. doi:10.1061/(asce)co.1943-7862.0001101.

8. Curtis HM, Meischke H, Stover B, Simcox NJ, Seixas NS. Gendered safety and health risks in the construction trades. Ann Work Expo Health. 2018;62:404-15. https://doi.org/10.1093/annweh/wxy006. 
9. Development Bureau of the Government of the Hong Kong Special Administrative Region Planning, Land and. Development B. https://sc.devb.gov.hk/TuniS/www.devb.gov.hk/tc/home/index.html (2018). Accessed 27 March 2020.

10. Didla S, Mearns K, Flin R. Safety citizenship behaviour: a proactive approach to risk management. J Risk Res. 2009;12:475-83. doi:10.1080/13669870903041433.

11. Falk CF, Biesanz JC. Two Cross-Platform Programs for Inferences and Interval Estimation About Indirect Effects in Mediational Models. SAGE Open. 2016;6:215824401562544. doi:10.1177/2158244015625445.

12. Fong BCH. One country, two nationalisms: center-periphery relations between Mainland China and Hong Kong, 1997-2016. Mod China. 2017;43:523-56. doi:10.1177/0097700417691470.

13. Fung IWH, Tam CM, Tung KCF, Man ASK. Safety cultural divergences among management, supervisory and worker groups in Hong Kong construction industry. Int J Proj Manag. 2005;23:504-12. doi:10.1016/j.ijproman.2005.03.009.

14. Galizzi M, Tempesti T. Workers' Risk Tolerance and Occupational Injuries. Risk Anal. 2015;35:1858-75. doi:10.1111/risa.12364.

15. Gordon LL. The Relationship Between Work-life Balance, Stress, and Injury in Construction Trade Workers. Master's dissertation. 2019; University of Washington. http://hdl.handle.net/1773/44219.

16. Hagger MS, Chatzisarantis NLD, Barkoukis V, Wang JCK, Hein V, Pihu M, Soós I, Karsai I. Cross-Cultural Generalizability of the Theory of Planned Behavior among Young People in a Physical Activity Context. J Sport Exerc Psychol. 2007;29:1-19. doi:10.1123/jsep.29.1.2.

17. Hair J, Black WC, Babin BJ. Anderson RE. Multivariate Data Analysis: International Version; Pearson Educaton. USA: Cranbury; 2010.

18. Harrington D. Confirmatory Factor Analysis. (Pocket Guides to Social Work Research Methods Series). New York: Oxford University Press; 2009.

19. Ho PHK. Labour and skill shortages in Hong Kong's construction industry. Eng Constr Archit Manag. 2016;23:533-50. doi:10.1108/ecam-12-2014-0165.

20. Hofmann DA, Morgeson FP. Safety-related behavior as a social exchange: The role of perceived organizational support and leadermember exchange. J Appl Psychol. 1999;84:286-96. doi:10.1037/0021-9010.84.2.286.

21. Hooper D, Coughlan J, Mullen M. Structural equation modelling: Guidelines for determining model fit. Electron J Bus Res Methods. 2008;6:53-60. http://www.ejbrm.com.

22. Idrees MD, Hafeez M, Kim JY. Workers' age and the impact of psychological factors on the perception of safety at construction sites. Sustainability. 2017;9:745. doi:10.3390/su9050745.

23. Ji Z, Pons D, Pearse J. Why do workers take safety risks? - A conceptual model for the motivation underpinning perverse agency. Safety. 2018;4:24. https://doi.org/10.3390/safety4020024.

24. Jones CA. Lost in China: Law, Culture and Identity in Post-1997 Hong Kong. Cambridge University. Cambridge University Press. 2016. p. 84. Doi:10.1007/9781316144916

25. Khan N, Ahmad I, llyas M. Impact of ethical leadership on organizational safety performance: the mediating role of safety culture and safety consciousness. Ethics Behav. 2018;28:628-43. https://doi.org/10.1080/10508422.2018.1427097.

26. Kocourkova J. Relationship between abortion and contraception: A comparative socio-demographic analysis of Czech and Slovak populations. Women health. 2016;56:885-905. https://doi.org/10.1080/03630242.2016.1141829.

27. Labour Department. Occupational Safety and Health Statistics Bulletin. https://www.labour.gov.hk/eng/osh/pdf/Bulletin2018_issue19_eng.pdf (2018). Accessed 27 March 2020.

28. LaMontagne AD, Martin A, Page KM, Reavley NJ, Noblet AJ, Milner AJ, Keegel T, Smith PM. Workplace mental health: developing an integrated intervention approach. BMC Psychiatry. 2014;14:131. doi:10.1186/1471-244X-14-131.

29. Lee J, Lee YK. Can working hour reduction save workers? Labour Econ. 2016;40:25-36. doi:10.1016/j.labeco.2016.02.004.

30. Li H, Lu M, Hsu SC, Gray M, Huang T. Proactive behavior-based safety management for construction safety improvement. Saf Sci. 2015;75:107-17. doi:10.1016/j.ssci.2015.01.013.

31. Li M, Zhai H, Zhang J, Meng X. Research on the Relationship Between Safety Leadership, Safety Attitude and Safety Citizenship Behavior of Railway Employees. Int J Environ Res Public Health. 2020;17(6):1864. doi:10.3390/ijerph17061864.

32. Li X, Chow KH, Zhu Y, Lin Y. Evaluating the impacts of high-temperature outdoor working environments on construction labor productivity in China: A case study of rebar workers. Build Environ. 2016;95:42-52. https://doi.org/10.1016/j.buildenv.2015.09.005.

33. Li Y, Ning Y, Chen WT. Critical Success Factors for Safety Management of High-Rise Building Construction Projects in China. Adv Civ Eng. 2018; 1-15. doi:10.1155/2018/1516354. 
34. Magnavita N. Productive aging, work engagement and participation of older workers: A triadic approach to health and safety in the workplace. Epidemiol Biostat Public Heal. 2017; 14. doi:https://doi.org/10.2427/12436.

35. Man SS, Chan AHS, Wong HM. Risk-taking behaviors of Hong Kong construction workers - A thematic study. Saf Sci. 2017;98:2536. doi:10.1016/j.ssci.2017.05.004.

36. Meng X, Chan AHS. Demographic influences on safety consciousness and safety citizenship behavior of construction workers. Saf Sci. 2020; 129: 104835. https://doi.org/10.1016/j.ssci.2020.104835

37. Meng X, Zhai H, Chan AHS. Development of Scales to Measure and Analyse the Relationship of Safety Consciousness and Safety Citizenship Behaviour of Construction Workers: An Empirical Study in China. Int J Environ Res Public Health. 2019;16:1411. doi:10.3390/ijerph16081411.

38. Mohammad H, Yaman SK, Hassan F, Ismail Z. Determining the technical competencies of construction managers in the Malaysia's construction industry. In MATEC Web of Conferences. EDP Sciences. 2016; 47: pp 04021. Doi: 10.1051/matecconf/20164704021.

39. National Bureau of Statistic of China. China Statistical Yearbook 2008-2018. http://www.stats.gov.cn/english/Statisticaldata/AnnualData/ (2020). Accessed 14th April 2020.

40. Ng JYK, Chan AH. The ageing construction workforce in Hong Kong: a review. Proceedings of the International Multi-Conference of Engineers and Computer Scientists, 2015; Vol II, Hong Kong. ISSN: 2078 - 0966.

41. Nie B, Huang X, Xue F, Chen J, Liu X, Meng Y, Huang J. A comparative study of vocational education and occupational safety and health training in China and the UK. Int J Occup Saf Ergon 2017; 1-10. doi:10.1080/10803548.2016.1270042.

42. Ong MHA, Puteh F. Quantitative Data Analysis: Choosing Between SPSS, PLS, and AMOS in Social Science Research. Int Interdiscip J Sci Res. 2017;3:14-25. www.iijsr.org.

43. Oxley J, O'Hern S, Jamaludin A. An observational study of restraint and helmet wearing behaviour in Malaysia. Transp Res Part $F$ Traffic Psychol Behav. 2018;56:176-84. doi:10.1016/j.trf.2018.03.028.

44. Park S, Oh S, Seok H, Kim SK, Choi JR, Oh SS, Koh SB. Long Working Hours and Poor Self-Rated Health in the Young Working Population in Korea. J Occup Environ Med. 2019;61:e291-6. doi:10.1097/jom.0000000000001606.

45. Peng L, Chan AH. Adjusting work conditions to meet the declined health and functional capacity of older construction workers in Hong Kong. Saf Sci. 2020;127:104711. doi:10.1016/j.ssci.2020.104711.

46. Peng L, Chan AHS. A meta-analysis of the relationship between ageing and occupational safety and health. Saf Sci. 2019;112:16272. doi:10.1016/j.ssci.2018.10.030.

47. Peng L, Chan AHS. Exerting Explanatory Accounts of Safety Behavior of Older Construction Workers within the Theory of Planned Behavior. Int J Environ Res Public Health. 2019;16:3342. doi:10.3390/ijerph16183342.

48. Pinion C, Klyza J, Brewer S, Douphrate D. North American Engineering, Procurement, Fabrication and Construction Worker Safety Climate Perception Affected by Job Position. Safety. 2018;4:14. doi:10.3390/safety4020014.

49. Podorova A, Irvine S, Kilmister M, Hewison R, Janssen A, Speziali A, Balavijendran A, Kek M, McAlinden M. An important, but neglected aspect of learning assistance in higher education: Exploring the digital learning capacity of academic language and learning practitioners. J Univ Teach Learn Pract. 2019;16:3. https://ro.uow.edu.au/jutlp/vol16/iss4/3.

50. Poscia A, Moscato U, La Milia DI, Milovanovic S, Stojanovic J, Borghini A, Collamati A, Ricciardi W, Magnavita N. Workplace health promotion for older workers: a systematic literature review. BMC Health Serv Res. 2016;16:329. doi:10.1186/s12913-016-1518-z.

51. Prussia GE, Willis GP, Rao M. Influences on safety consciousness in a utility company: A sequential mediation model. J Safety Res. 2019;68:119-29. doi:10.1016/j.jsr.2018.12.002.

52. Rouder JN, Engelhardt CR, McCabe S, Morey RD. Model comparison in ANOVA. Psychon Bull Rev. 2016;23:1779-86. doi:10.3758/s13423-016-1026-5.

53. Rowlinson SM. Hong Kong construction-safety management and the law. Hong Kong: Sweet \& Maxwell Asia; 2003.

54. Savalei V. Improving Fit Indices in Structural Equation Modeling with Categorical Data. Multivariate Behav Res. 2020; 1-18. doi:10.1080/00273171.2020.1717922.

55. Schwatka NV, Rosecrance JC. Safety climate and safety behaviors in the construction industry: The importance of co-workers commitment to safety. Work. 2016;54:401-13. doi:10.3233/wor-162341.

56. Shao B, Hu Z, Liu Q, Chen S, He W. Fatal accident patterns of building construction activities in China. Saf Sci. 2018;111:253-63. doi:10.1016/j.ssci.2018.07.019. 
57. She KH, Siu OL, Phillips DR. Safety attitudes and safety performance among older and younger workers in Hong Kong and China. Congress of Gerontology. Hong Kong Association of Gerontology. 2000.

58. Skibiński A, Sipa M, Gorzeń-Mitka I. An intergenerational cooperation in the organization-view from the age perspective. ProcediaSocial Behav Sci. 2016;235:412-9. doi:10.1016/j.sbspro.2016.11.051.

59. Skogstad M, Mamen A, Lunde LK, Ulvestad B, Matre D, Aass HCD, Øvstebø R, Nielsen P, Samuelsen KN, Skare $\varnothing$, Sirnes PA. Shift Work Including Night Work and Long Working Hours in Industrial Plants Increases the Risk of Atherosclerosis. Int J Environ Res Public Health. 2019;16:521. doi:10.3390/ijerph16030521.

60. Stoilkovska BB, Žileska Pančovska V, Mijoski G. Relationship of safety climate perceptions and job satisfaction among employees in the construction industry: the moderating role of age. Int J Occup Saf Ergon. 2015;21:440-7. doi:10.1080/10803548.2015.1096059.

61. Tan Y, Xue B, Cheung YT. Relationships between Main Contractors and Subcontractors and Their Impacts on Main Contractor Competitiveness: An Empirical Study in Hong Kong. J Constr Eng Manag. 2017;143:05017007. doi:10.1061/(asce)co.19437862.0001311.

62. Tavakol M, Dennick R. Making sense of Cronbach's alpha. Int J Med Educ. 2011;2:53-5. doi:10.5116/ijme.4dfb.8dfd.

63. The introduction of Hong Kong Occupational Safety and Health Council. http://www.oshc.org.hk/oshc_data/files/Aboutus/OSHCProfile/25th_History_panel.pdf (2014). Accessed 27 March 2020.

64. Tsai R, Alterman T, Grosch JW, Luckhaupt SE. Availability of and Participation in Workplace Health Promotion Programs by Sociodemographic, Occupation, and Work Organization Characteristics in US Workers. Am J Heal Promot. 2019; 089011711984447. doi:10.1177/0890117119844478.

65. Vaismoradi M, Griffiths $\mathrm{P}$, Turunen $\mathrm{H}$, Jordan S. Transformational leadership in nursing and medication safety education: a discussion paper. J Nurs Manag. 2016; 24: 970-980. doi:10.1111/jonm.12387.

66. Vanttola P, Puttonen S, Karhula K, Oksanen T, Härmä M. Prevalence of shift work disorder among hospital personnel: A crosssectional study using objective working hour data. J Sleep Res. 2019. doi:10.1111/jsr.12906.

67. Villanueva G, Fitch T, Quadir MM, Raju Sagiraju HK, Alamgir H. Self-efficacy, disability level and physical strength in the injured workers: findings from a major factory disaster in Bangladesh. Disabil Rehabil. 2017;39:677-83.

doi:10.3109/09638288.2016.1161085.

68. Wu C, Luo X, Wang T, Wang Y, Sapkota B. Safety challenges and improvement strategies of ethnic minority construction workers: a case study in Hong Kong. Int J Occup Saf Ergon. 2018; 1-11. doi:10.1080/10803548.2018.1466508.

69. Yang F, Li X, Zhu Y, Li Y, Wu C. Job burnout of construction project managers in China: A cross-sectional analysis. Int J Proj Manag. 2017;35:1272-87. doi:10.1016/j.jproman.2017.06.005.

70. Yeung $S$. The review of one country two systems of Hong Kong over two decades from the perspective of social development: The challenges and prospect. Asian Educ Dev Stud. 2019;8:511-22. doi:10.1108/AEDS-06-2017-0054.

71. Ying KC, Zhang G, Setunge S. Key Parameters on Financial Loss of Construction Accidents in Hong Kong Construction Industry. Proceedings of the 21st International Symposium on Advancement of Construction Management and Real Estate, 2017; p. 957967. doi:10.1007/978-981-10-6190-5_86.

72. Yiu NS, Sze NN, Chan DW. Implementation of safety management systems in Hong Kong construction industry-A safety practitioner's perspective. J Safety Res. 2018;64:1-9. doi:10.1016/j.jsr.2017.12.011.

73. Yu G. Employment of Older Workers in China: The State and the Life Course. Doctor of Philosophy dissertation, 2016; Jacobs University. doi: 10.13140/RG.2.2.27277.03044.

74. Zhang J, Zhai H, Meng X, Wang W, Zhou L. Influence of Social Safety Capital on Safety Citizenship Behavior: The Mediation of Autonomous Safety Motivation. Int J Environ Res Public Health. 2020;17:866. https://doi.org/10.3390/ijerph17030866.

75. Zhang P, Li N, Fang D, Wu H. Supervisor-Focused Behavior-Based Safety Method for the Construction Industry: Case Study in Hong Kong. J Constr Eng Manag. 2017;143:05017009. doi:10.1061/(asce)co.1943-7862.0001294.

76. Zhang Z, An SH. A comparative analysis of the safety awareness of Korean and Chinese construction workers. J Korea Inst Build Constr. 2011;12:433-41. https://doi.org/10.5345/JKIBC.2012.12.4.433.

\section{Figures}




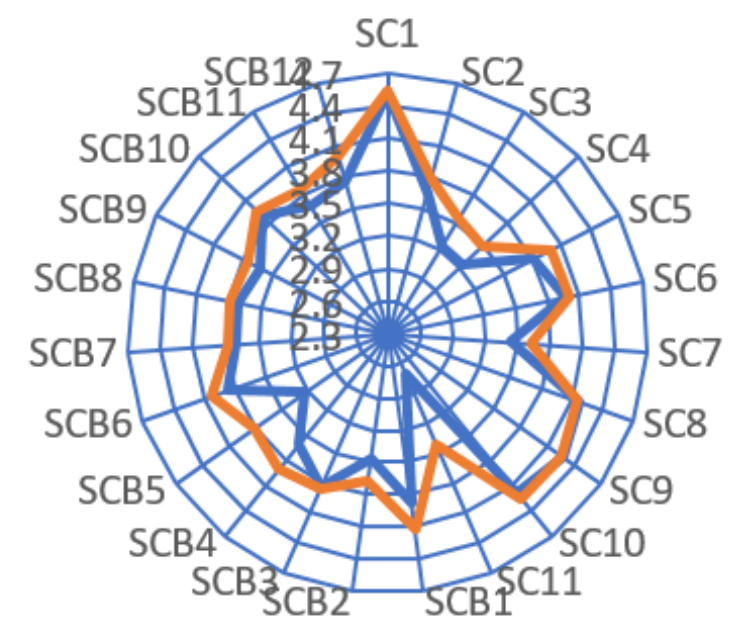

Mainland China $\longrightarrow$ Hong Kong

\section{Figure 1}

SC and SCB profiles of construction workers from Mainland China and Hong Kong.

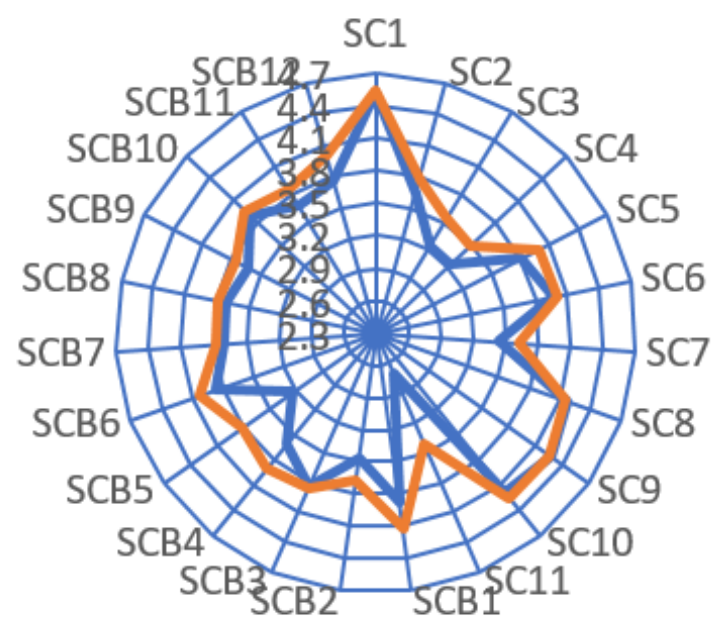

Mainland China $\longrightarrow$ Hong Kong

Figure 1

SC and SCB profiles of construction workers from Mainland China and Hong Kong. 


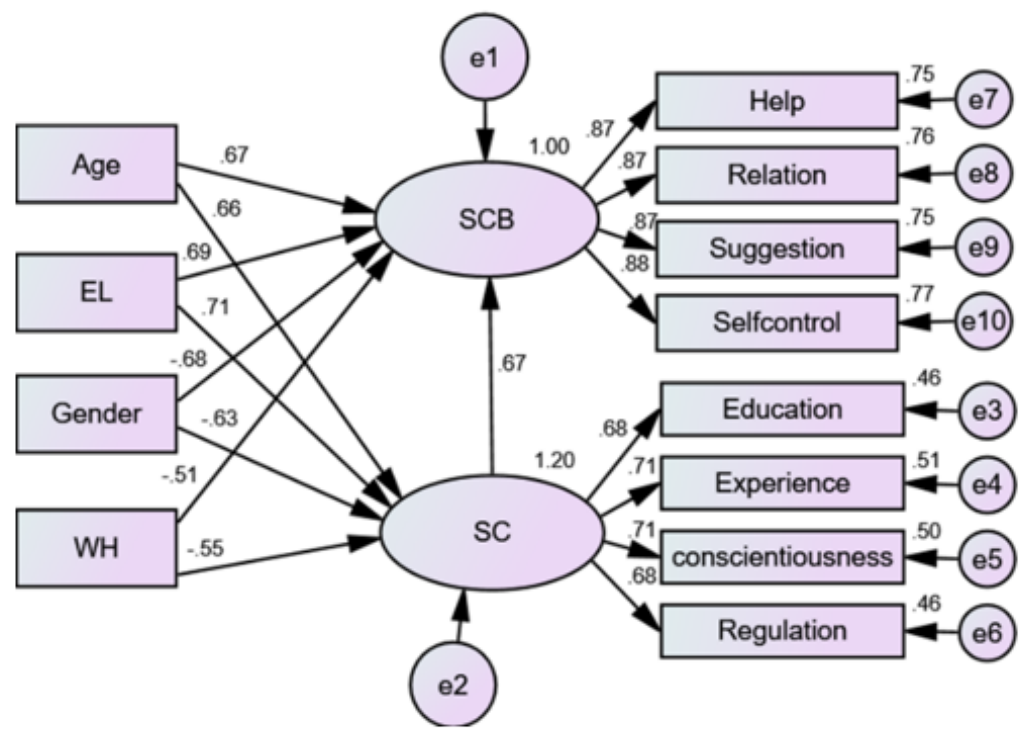

Figure 2

Structural equation model of the demographic influence on the SC and SCB in MC.

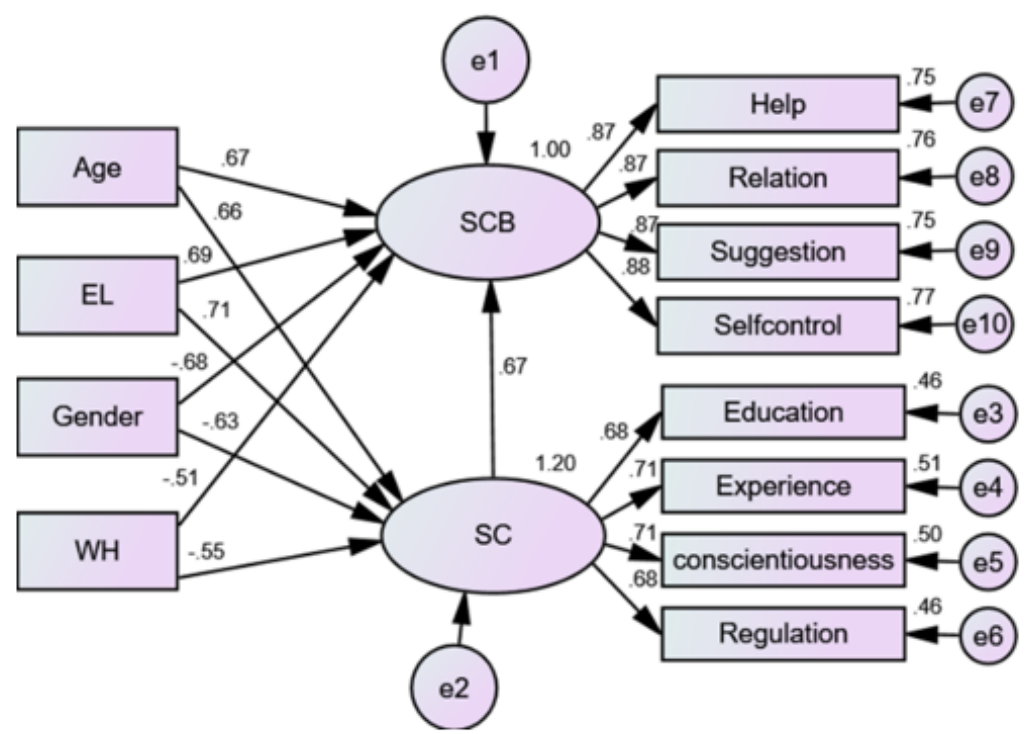

Figure 2

Structural equation model of the demographic influence on the SC and SCB in MC. 


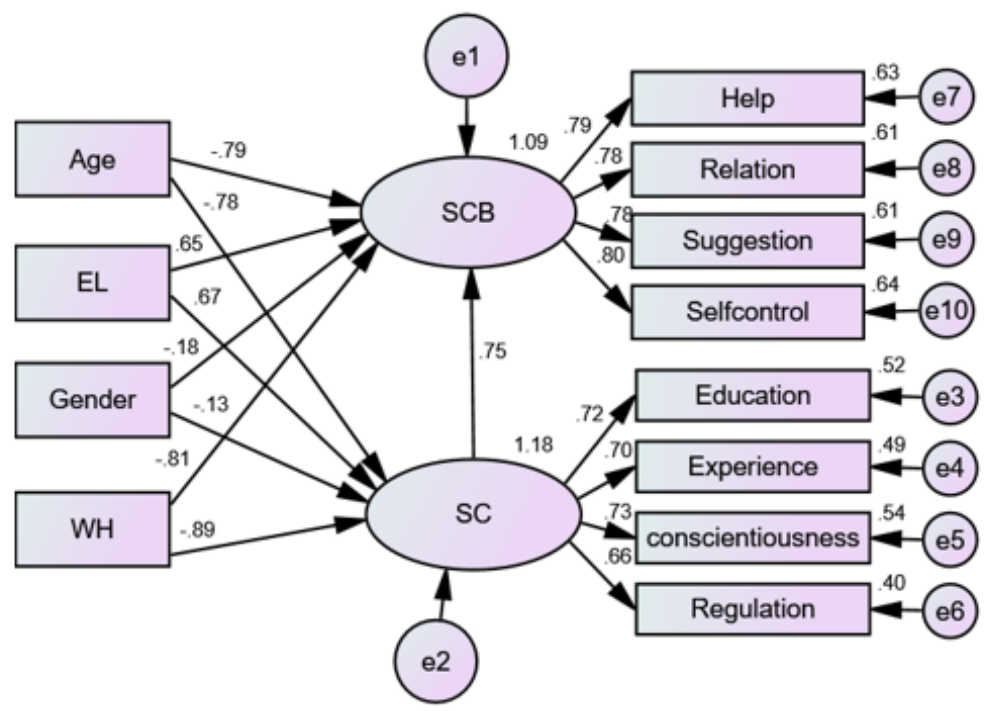

Figure 3

Structural equation model of the demographic influence on the SC and SCB in HK.

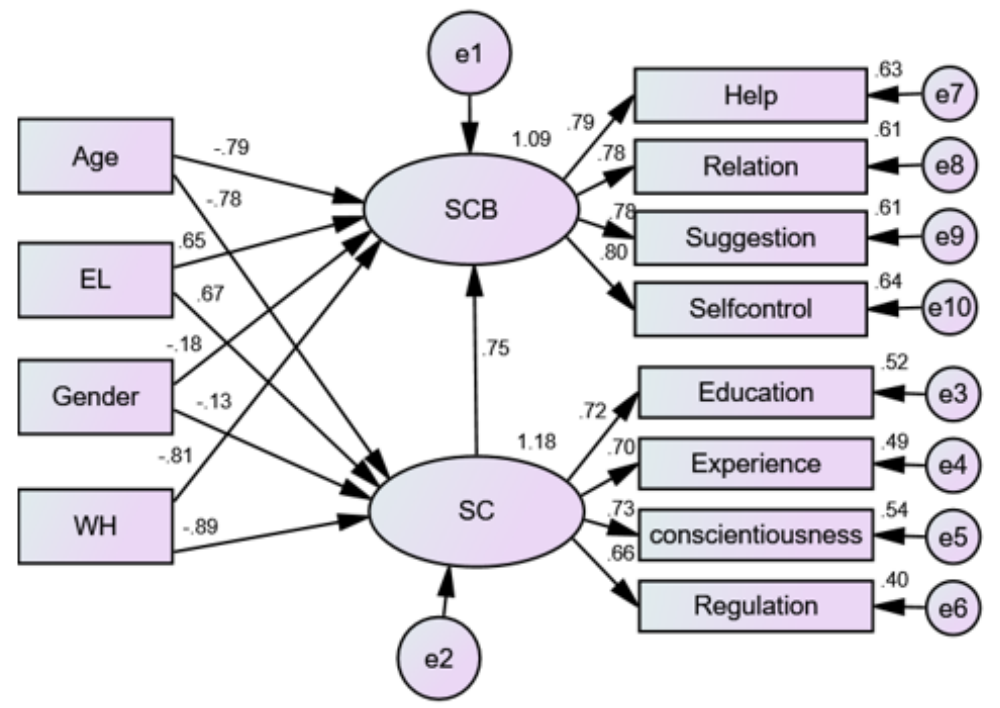

\section{Figure 3}

Structural equation model of the demographic influence on the SC and SCB in HK. 